\title{
A Single-Chain Nanoparticle Delivers a Partner Enzyme for Concurrent and Tandem Catalysis in Cells
}

\author{
Junfeng Chen $,{ }^{\dagger} \mathrm{Ke} \mathrm{Li},{ }^{\dagger}$ Jiseon "Lucy" Shon,${ }^{\dagger}$ and Steven C. Zimmerman*,†,
}

'Department of Chemistry, University of Illinois, Urbana, Illinois 61801, United States.

Center for Biophysics and Quantitative Biology, University of Illinois, Urbana, Illinois 61801, United States.

\section{Contents}

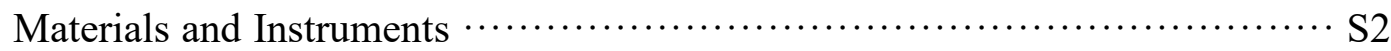

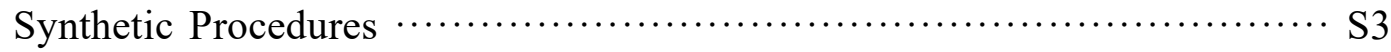

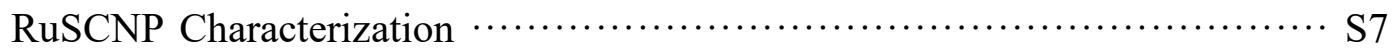

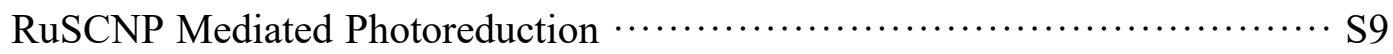

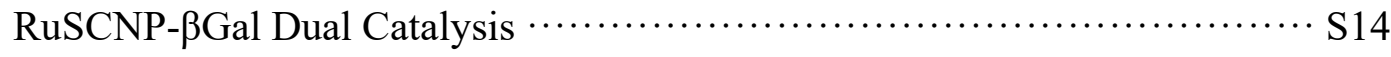

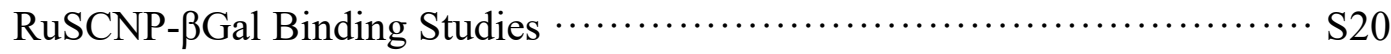

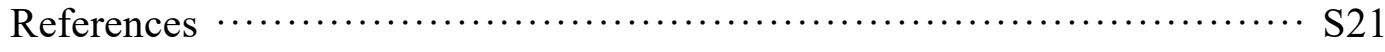




\section{Materials and Instruments}

All reagents were purchased from Acros Organics, Fisher Scientific, Cambridge Chemical Technologies, Chem-Impex International, AK Scientific, TCI America, ProteinMods, or Sigma-Aldrich, and used without further purification unless otherwise noted. For the synthetic procedures, DCM, THF, acetonitrile, DMSO and DMF were stored over activated $4 \AA$ molecular sieves. NMR spectra were recorded using Varian U500, Bruker CB500 or VNS750NB spectrometers in the NMR Laboratory, School of Chemical Science, University of Illinois. Spectra were processed by using MestReNova (v8.1). The chemical shift $(\delta)$ is listed in ppm and the coupling constants $(J)$ are in Hz. Mass spectral analyses were provided by the Mass Spectrometry Laboratory, School of Chemical Science, University of Illinois, using ESI on a Waters Micromass Q-Tof spectrometer, FD on a Waters 70-VSE spectrometer and MALDI on a Bruker Daltonics UltrafleXtreme MALDI TOF. Transmission electron microscopy (TEM) was performed on a JEOL 2100

Cryo TEM, Materials Research Laboratory, University of Illinois at Urbana-Champaign. Fluorescence experiments were performed on a Horiba FluoroMax-4 fluorometer with FluorEssence (v3.5) software. Fluorescence polarization experiments were performed on an Analyst HT plate reader. Confocal microscopy studies were performed on a Leica SP8 UV/Visible Laser Confocal Microscope. The RAW data files were processed using OriginPro2017 and imported into Adobe Illustrator CC for coloring and annotation. 


\section{$\underline{\text { Synthetic Procedures }}$}

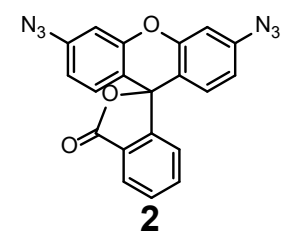

Compound $\mathbf{2}$ was prepared using the reported procedure. ${ }^{1}$

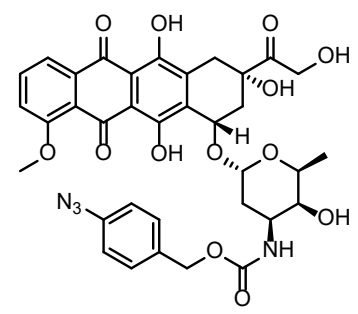

6

Compound 6 was prepared using the reported procedure. ${ }^{2}$

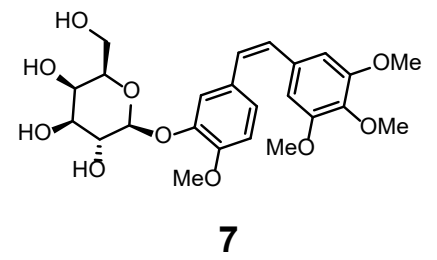

Compound 7 was prepared using the reported procedure. ${ }^{3}$

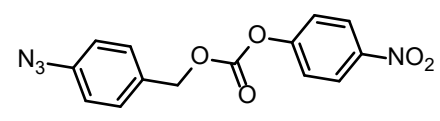

10

Compound 7 was prepared using the reported procedure. ${ }^{4}$ 
Synthesis of the di-alkyne derivative of bipyridine (9)

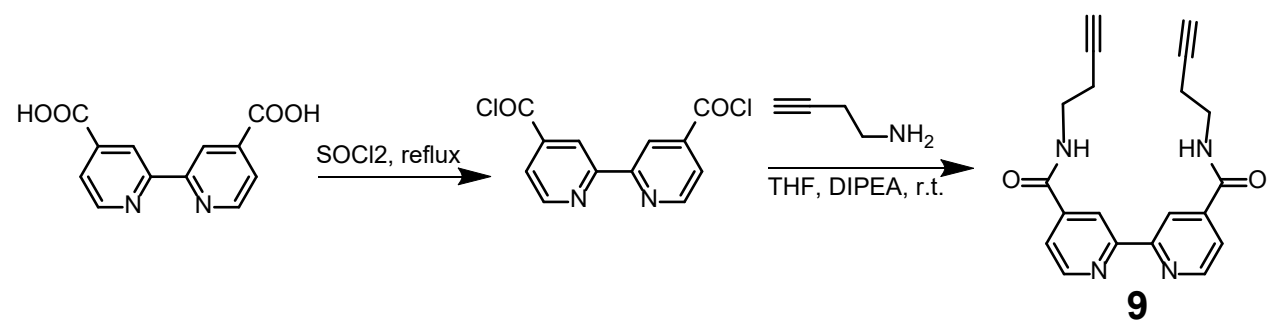

In a $50 \mathrm{~mL}$ round bottom flask, $2.44 \mathrm{~g}(10 \mathrm{mmol})$ of 2,2'-bipyridine-4,4'-dicarboxylic acid was suspended in $8 \mathrm{~mL}$ of thionyl chloride, and the mixture was stirred at reflux condition for $16 \mathrm{~h}$. Thionyl chloride was removed by using a rotary evaporator, and the crude product was dried under high vacuum. The resulting solid was redissolved in a mixture of $30 \mathrm{~mL}$ of SPS dried THF and $5 \mathrm{~mL}$ of DIPEA, and $1.73 \mathrm{~g}(25 \mathrm{mmol}$, $1.25 \mathrm{eq}$ ) of 1-amino-3-butyne was added dropwise. The mixture was stirred at room temperature for $12 \mathrm{~h}$. Volatiles were removed by using a rotary evaporator, and the resulting pink solid was washed with $30 \mathrm{~mL}$ of water five times, and $10 \mathrm{~mL}$ of DCM twice to afford $2.1 \mathrm{~g}(61 \%)$ of the title compound as an off-white solid. ${ }^{1} \mathrm{H}$ NMR $\left(500 \mathrm{MHz}, \mathrm{CDCl}_{3}\right): \delta 8.75(\mathrm{~d}, J=5.0,2 \mathrm{H}), 8.62(\mathrm{~s}, 2 \mathrm{H}), 7.74(\mathrm{~d}, J=5.0,2 \mathrm{H}), 6.88(\mathrm{~s}, 2 \mathrm{H})$, $3.61(\mathrm{q}, J=6.3,4 \mathrm{H}), 2.51(\mathrm{~m}, 4 \mathrm{H}), 2.00(\mathrm{t}, J=2.4,2 \mathrm{H}) .{ }^{13} \mathrm{C}$ NMR: $\left(125 \mathrm{MHz}, \mathrm{CDCl}_{3}\right): \delta 165.5,156.1$, $150.3,142.7,122.2,117.6,81.2,70.6,38.7,19.4$. High resolution ESI-MS: $m / z$ calculated for $\mathrm{C}_{20} \mathrm{H}_{19} \mathrm{~N}_{4} \mathrm{O}_{2}$ $\left([\mathrm{M}+\mathrm{H}]^{+}\right): 347.1508$; found 347.1500 .

\section{Synthesis of the di-alkyne derivative of $\operatorname{Ru}(\mathrm{bpy})_{3}(1)$}
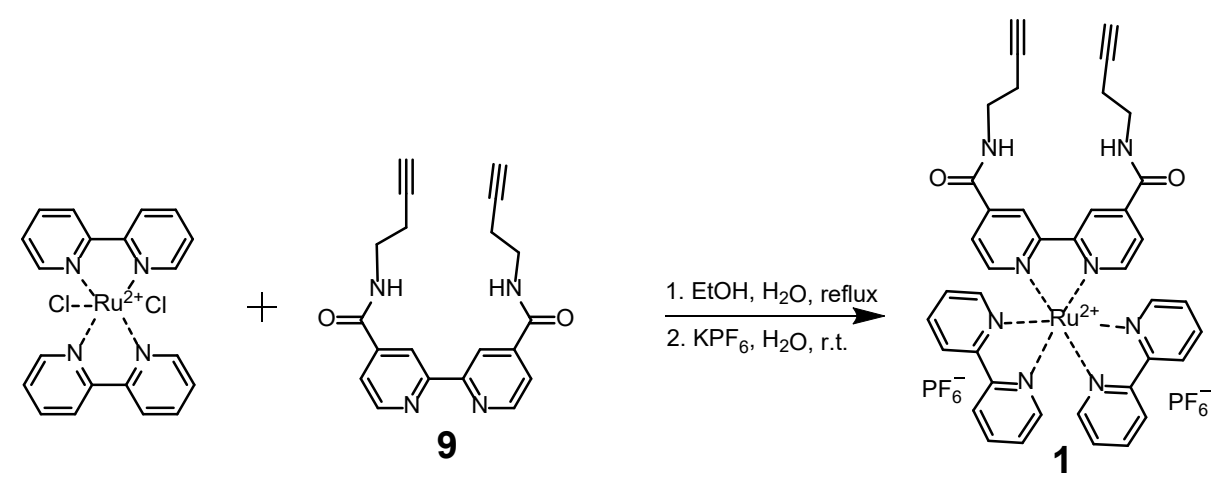

In a $100 \mathrm{~mL}$ round bottom flask, $500 \mathrm{mg}(1.03 \mathrm{mmol})$ of $\mathrm{Ru}_{2}(\text { bpy })_{2} \mathrm{Cl}_{2}$ and $536 \mathrm{mg}(1.55 \mathrm{mmol}, 1.5 \mathrm{eq})$ of 9 were suspended in a mixture of $30 \mathrm{~mL}$ of EtOH and $10 \mathrm{~mL}$ of water. The mixture was stirred in an aluminum-wrapped flask and heated to reflux for $16 \mathrm{~h}$ under $\mathrm{N}_{2}$ with the laboratory lights off. Ethanol was removed by using a rotary evaporator, and $20 \mathrm{~mL}$ of water was added to the resulting mixture. The aqueous solution was filtrated to remove insoluble impurities. To the mixture was added $5 \mathrm{~mL}$ of a saturated aqueous solution of $\mathrm{KPF}_{6}$, and the orange-red colored precipitate was collected by filtration. The solid was purified by column chromatography on neutral $\mathrm{Al}_{2} \mathrm{O}_{3}$ with a gradient from $\mathrm{DCM}$ to acetonitrile to afford $0.55 \mathrm{~g}$ $(51 \%)$ of the title compound as an orange-red solid. ${ }^{1} \mathrm{H}$ NMR $\left(500 \mathrm{MHz}, \mathrm{CDCl}_{3}\right.$ and $\left.\mathrm{CD}_{3} \mathrm{OD}\right): \delta 8.83(\mathrm{~s}$, $2 \mathrm{H}), 8.34(\mathrm{~m}, 4 \mathrm{H}), 7.90(\mathrm{~m}, 4 \mathrm{H}), 7.66(\mathrm{~m}, 4 \mathrm{H}), 7.53(\mathrm{~d}, J=5.2,4 \mathrm{H}), 7.30(\mathrm{~m}, 4 \mathrm{H}), 3.40(\mathrm{t}, J=6.0,4 \mathrm{H})$. $2.34(\mathrm{td}, J=6.0,2.5,4 \mathrm{H}) .1 .27(\mathrm{t}, J=2.5,2 \mathrm{H}) .{ }^{13} \mathrm{C} \mathrm{NMR}:\left(125 \mathrm{MHz}, \mathrm{CDCl}_{3}\right.$ and $\left.\mathrm{CD}_{3} \mathrm{OD}\right): \delta 163.9,157.1$, 156.4, 151.8, 151.2, 151.0, 142.7, 138.3, 128.1, 128.1, 125.6, 124.2, 122.0 80.7, 69.9, 39.0 18.6. High resolution ESI-MS: $m / z$ calculated for $\mathrm{C}_{40} \mathrm{H}_{34} \mathrm{~N}_{8} \mathrm{O}_{2} \mathrm{Ru}^{2+}\left([\mathrm{M}]^{2+}\right)$ : 759.1850; found 759.1781. 
Synthesis of the azido masked galactose-coumarin derivative (8)

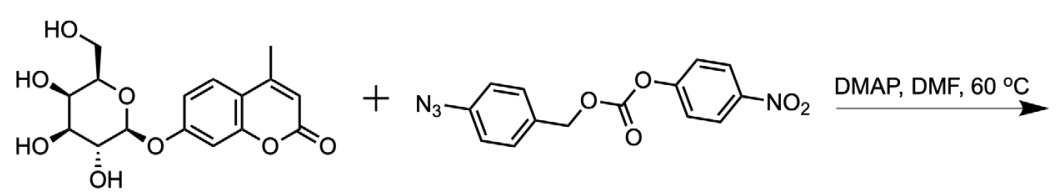

4

10

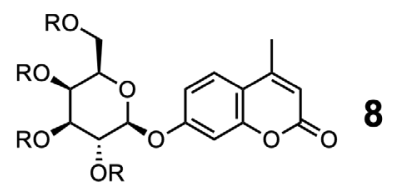

$2 \mathrm{R}=\mathrm{H}$

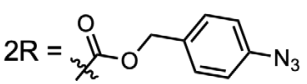

In a $20 \mathrm{~mL}$ glass vial, $169 \mathrm{mg}(0.50 \mathrm{mmol})$ of $4,314 \mathrm{mg}(1.0 \mathrm{mmol})$ of 10 and $122 \mathrm{mg}(1.0 \mathrm{mmol})$ of DMAP were dissolved in $10 \mathrm{~mL}$ of SPS dried DMF. The vial was screwed and sealed, and the mixture was stirred at $60{ }^{\circ} \mathrm{C}$ under $\mathrm{N}_{2}$ for $12 \mathrm{~h}$. The mixture was cooled to room temperature and precipitated in $40 \mathrm{~mL}$ of water. The precipitates were collected through centrifugation and dried on a lyophilizer. The crude product was purified through the silica column chromatography with a gradient from DCM to DCM : ethyl acetate (3:1, $\mathrm{v} / \mathrm{v})$ to afford $83 \mathrm{mg}(24 \%)$ of the title compound as a white solid. High resolution ESI-MS: $\mathrm{m} / \mathrm{z}$ calculated for $\mathrm{C}_{33} \mathrm{H}_{31} \mathrm{~N}_{6} \mathrm{O}_{11}\left([\mathrm{M}+\mathrm{H}]^{+}\right)$: 687.1973; found 687.1578.

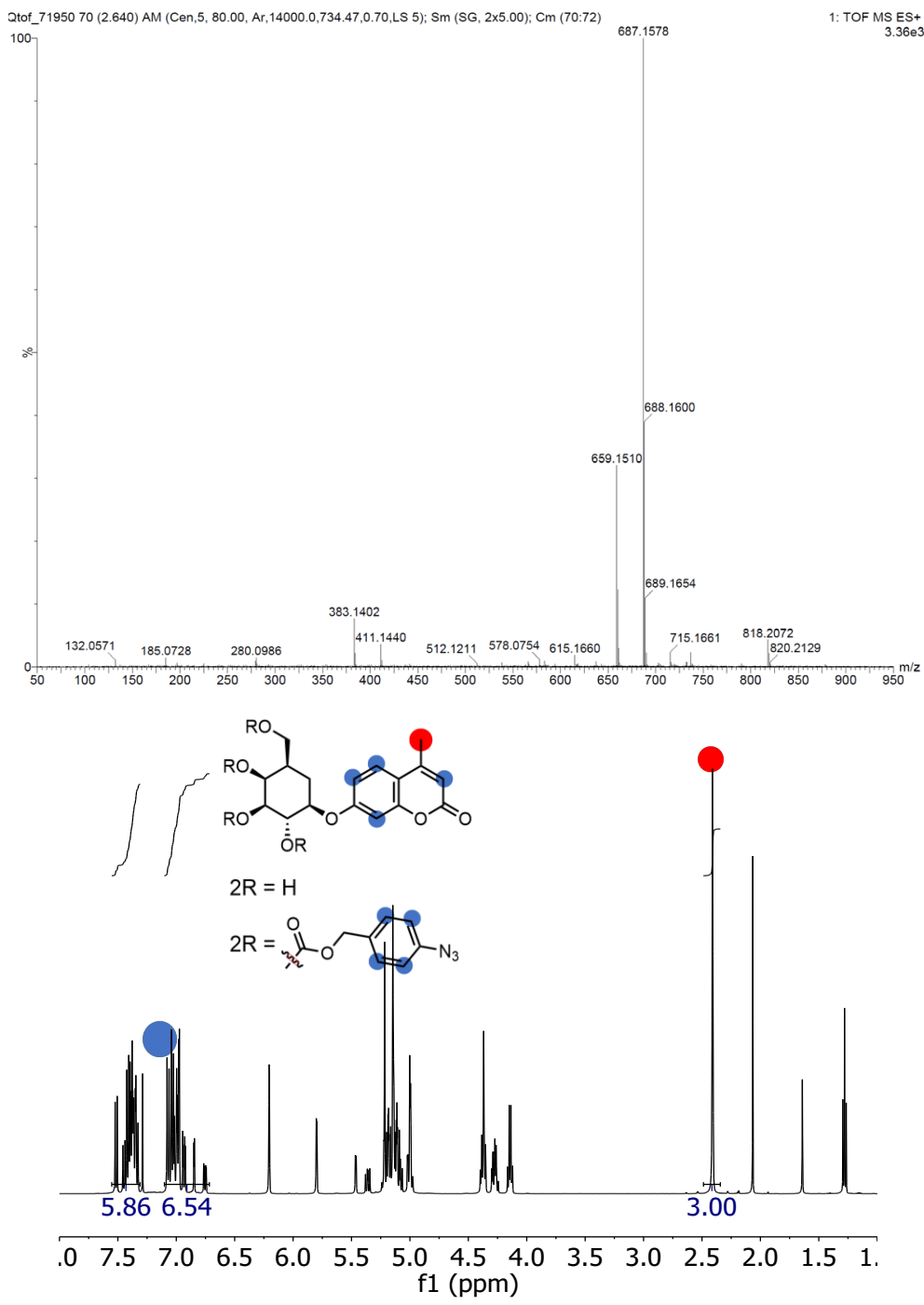




\section{Synthesis of RuSCNP}

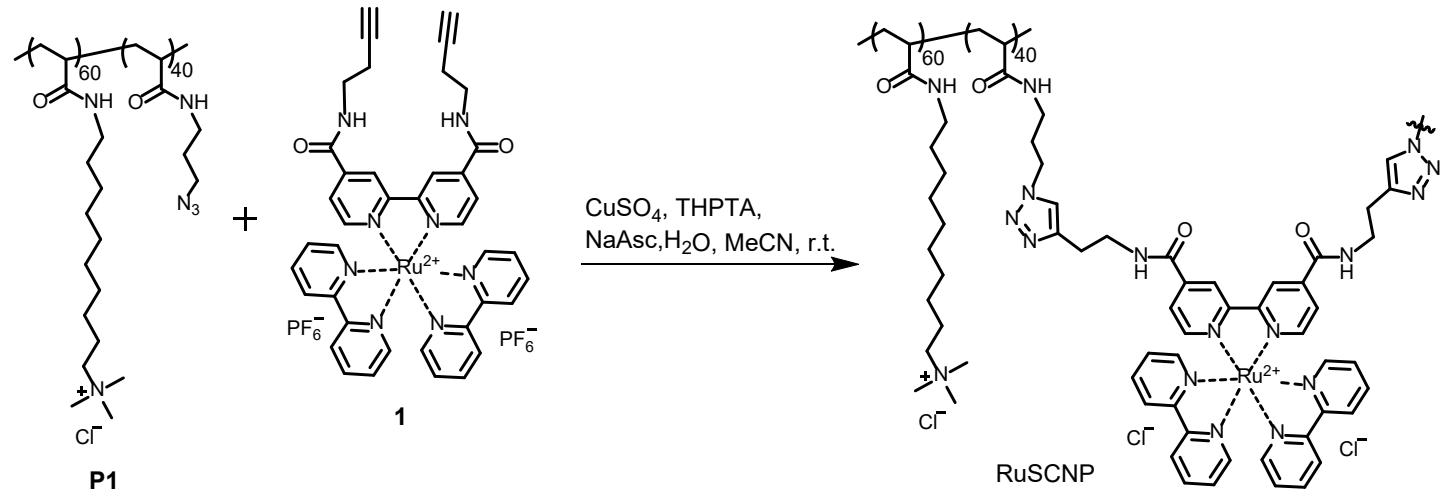

Compound 1 was prepared as a $10 \mathrm{mM}$ solution in $\mathrm{MeCN}$. THPTA-Cu was prepared as a $20 \mathrm{mM}$ solution in water with 1:1 molar ratio between THPTA ligand and $\mathrm{CuSO}_{4}$. Sodium ascorbate (NaAsc) was prepared as a $200 \mathrm{mM}$ solution in water. P1 was prepared as a $500 \mu \mathrm{M}$ solution in water. ${ }^{5}$

In a $500 \mathrm{~mL}$ round bottom flask, $200 \mathrm{~mL}$ total volume of water, $\mathbf{P 1}$ was added to reach a concentration of $25 \mu \mathrm{M}$. THPTA-Cu was added to reach a concentration of $250 \mu \mathrm{M}$ and $\mathbf{1}$ solution was added to reach a concentration of $500 \mu \mathrm{M}$. NaAsc was added to reach a concentration of $2 \mathrm{mM}$. The mixture was stirred at room temperature for $16 \mathrm{~h}$ under $\mathrm{N}_{2}$. The solution was purified by using an Amicon tube with $10 \mathrm{kDa}$ cutoff: the polymer solution was concentrated to about $10 \mathrm{~mL}$ and subsequently washed three times with $0.2 \mathrm{M}$ $\mathrm{NaCl}(\mathrm{aq})$ and six times with Milli Q water. The resulting solution was lyophilized to afford an orange-red solid. The yield of this step typically ranges from $80-90 \%$.

\section{Preparation of fluorescein labeled beta-galactosidase ( $\beta$ GalF)}

In a $1.5 \mathrm{~mL}$ centrifuge tube, $200 \mu \mathrm{L}$ of $5 \mu \mathrm{M}$ beta-galactosidase in PBS buffer $(1 \mathrm{X}, \mathrm{pH}=7.4)$ was added 4 $\mu \mathrm{L}$ of $2 \mathrm{mM}$ FITC-NHS solution in DMSO to reach $40 \mu \mathrm{M}$ final concentration, and the solution was gently shaken for $4 \mathrm{~h}$ at room temperature. The protein was purified by using an Amicon tube with $30 \mathrm{kDa}$ cutoff with Milli Q water (6 times). 


\section{RuSCNP Characterization}

\section{Transmission electron microscopy (TEM)}

A $2 \mu \mathrm{M}$ solution of RuSCNP in fresh Milli-Q water $(8 \mu \mathrm{L})$ or a mixture of $200 \mathrm{nM}$ of RuSCNP and $20 \mathrm{nM}$ of $\beta \mathrm{Gal}$ in PBS buffer was applied to a UC-A on lacey gold TEM grid (Ted Pella) for $20 \mathrm{~min}$. The SCNP solution was carefully removed by using a filter paper to absorb the solution. Ammonium molybdate ( $2 \mathrm{wt} \%$ in water, $8 \mu \mathrm{L}$ ) was added to the grid surface to negatively stain the SCNP. The staining process was conducted for $20 \mathrm{~min}$ and the solution was removed using a filter paper. The TEM grid was allowed to air dry for $1 \mathrm{~h}$. The TEM imaging was performed on a JEOL 2100 Cryo TEM with $200 \mathrm{keV}$, and the images were processed using ImageJ.

\section{Relaxation Time $T_{2}$ Determination and DOSY Experiment}

The NMR solution of RuSCNP $(100 \mu \mathrm{M})$ in DMSO- $d_{6}$ was prepared and measured by NMR. Proton spinspin relaxation time $T_{2}$ was determined by using Carr-Purchell-Meiboom-Gill pulse sequence on a U500 spectrometer. The data was processed by MestreNova 8.1, and the peak integrations of the $\mathrm{Ru}(\mathrm{bpy})_{3}$ unit (8.7-7.2 ppm), trimethyl ammonium groups (3.0 ppm) and hydrophobic allyl chains (1.2 ppm) were fitted to a mono-exponential function: $\mathrm{M}_{\mathrm{xy}}(\mathrm{t})=\mathrm{M}_{\mathrm{xy}}(0) \mathrm{e}^{-\mathrm{t} / \mathrm{T} 2}$ to calculate $\mathrm{T}_{2}$. Diffusion ordered spectroscopy (DOSY) experiments were performed on a VNS750 spectrometer through the pulse sequence that encodes the Z-gradient amplifier. The diffusion coefficients were calculated from Stejskal-Tanner function. Hydrodynamic diameters were calculated from Stokes-Einstein equation. The data for P1 was adapted from our previous report. ${ }^{5}$ 


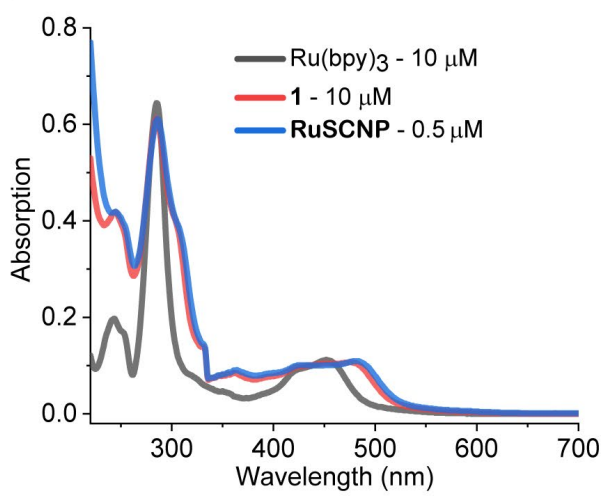

b

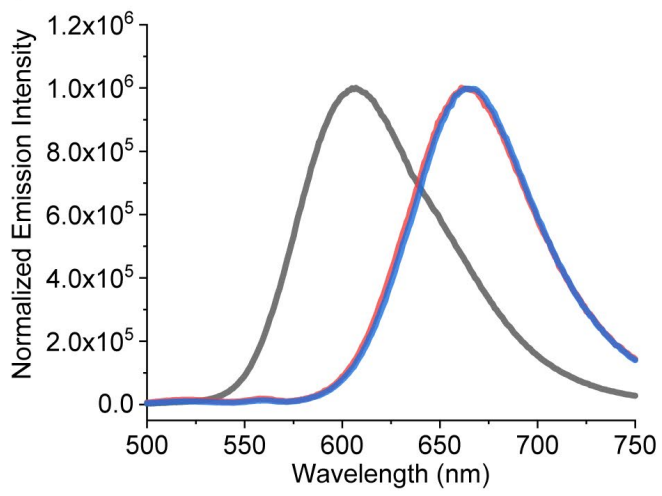

C

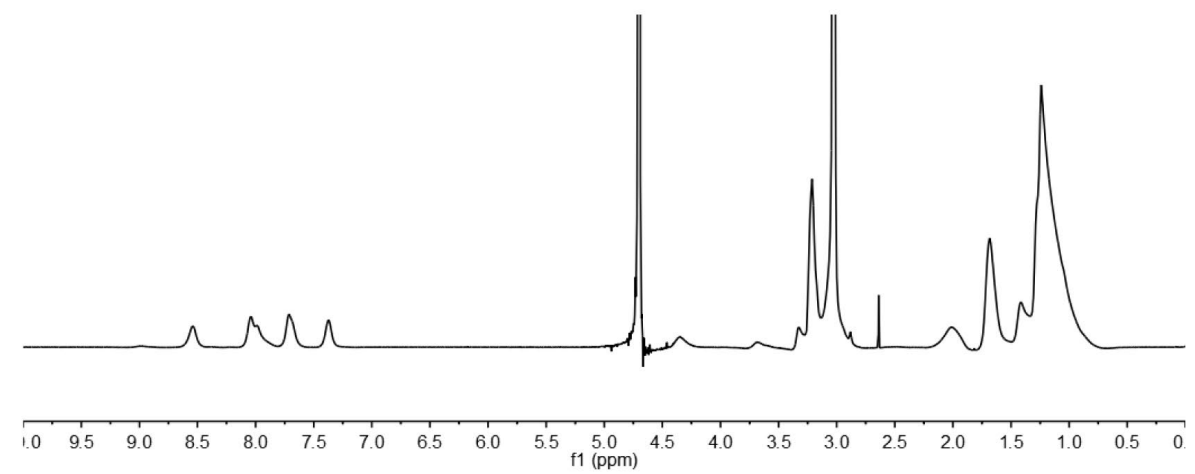

d

\begin{tabular}{|c|c|c|}
\hline & P1 & RuSCNP \\
\hline DOSY-Diameter & $7.8 \mathrm{~nm}$ & $7.3 \mathrm{~nm}$ \\
\hline $\mathrm{T}_{2}-\mathrm{N}\left(\mathrm{CH}_{3}\right)_{3}$ & $145 \mathrm{~ms}$ & $69 \mathrm{~ms}$ \\
\hline $\mathrm{T}_{2}-\left(\mathrm{CH}_{2}\right)_{6}$ & $31 \mathrm{~ms}$ & $19 \mathrm{~ms}$ \\
\hline $\mathrm{T}_{2}-\mathrm{Ru}(\mathrm{bpy})_{3}$ & - & $12 \mathrm{~ms}$ \\
\hline
\end{tabular}

e
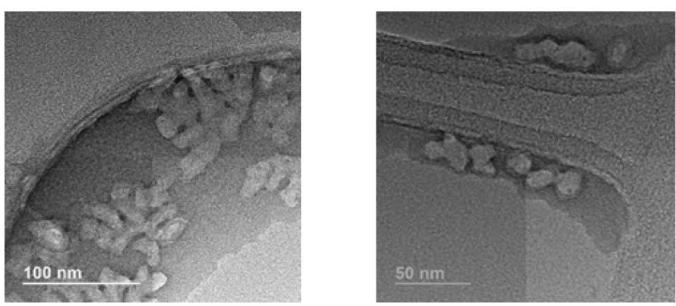

Figure S1. Characterization of RuSCNP. (a) the UV-Vis spectra of RuSCNP $(0.5 \mu \mathrm{M}), 1(10 \mu \mathrm{M})$ and $\mathrm{Ru}(\mathrm{bpy})_{3}(10 \mu \mathrm{M})$ in PBS buffer $(1 \mathrm{x}, \mathrm{pH}=7.4)$ at room temperature. (b) the emission spectra of $\operatorname{RuSCNP}(0.5 \mu \mathrm{M}), 1(10 \mu \mathrm{M})$ and $\mathrm{Ru}(\mathrm{bpy})_{3}(10 \mu \mathrm{M})$ in PBS buffer $(1 \mathrm{x}, \mathrm{pH}=7.4)$ excited at $470 \mathrm{~nm}$ at room temperature. (c) the NMR spectrum of RuSCNP measured in $\mathrm{D}_{2} \mathrm{O}$. (d) the proton relaxation time $\mathrm{T}_{2}$ and DOSY measured diameters of P1 and RuSCNP DMSO-d6 at $100 \mu \mathrm{M}$ measured by NMR. (e) TEM images of the mixture of RuSCNP $(200 \mathrm{nM})$ and $\beta \mathrm{Gal}(20 \mathrm{nM})$. 


\section{RuSCNP Mediated Photoreduction}

\section{Photoreduction of 2 in PBS buffer}

Stock solutions were prepared as follows: $\operatorname{RuSCNP}(5 \mu \mathrm{M})$ in water, $1(100 \mu \mathrm{M})$ in a mixture of water and $\operatorname{MeCN}(9: 1, \mathrm{v} / \mathrm{v}), \mathrm{Ru}(\mathrm{bpy})_{3}(100 \mu \mathrm{M})$ in water, $2(1 \mathrm{mM})$ in DMSO, NaAsc $(200 \mathrm{mM})$ in water. In a $20 \mathrm{~mL}$ glass vial covered by aluminum foil, the catalyst, 2 and NaAsc were added to $1 \mathrm{~mL}$ of PBS buffer. The final concentrations were: $[\mathbf{R u S C N P}]=50 \mathrm{nM},[\mathbf{1}]=1 \mu \mathrm{M}$ or $\left[\mathrm{Ru}(\mathrm{bpy})_{3}\right]=1 \mu \mathrm{M},[2]=5 \mu \mathrm{M},[\mathrm{NaAsc}]=2 \mathrm{mM}$. The vial was irradiated by M470L3 at $1 \mathrm{~A}$ for $2 \mathrm{~min}, 5 \mathrm{~min}$ or $10 \mathrm{~min}$. After irradiation the solution was diluted 100 times in PBS buffer in a $4 \mathrm{~mL}$ quartz cuvette and measured by a fluorometer. Ex: $490 \mathrm{~nm}$, Em: $521 \mathrm{~nm}$. The conversion was determined by using pure 3 as the standard. Control experiments were conducted without either irradiation, NaAsc, or RuSCNP.

\section{a}

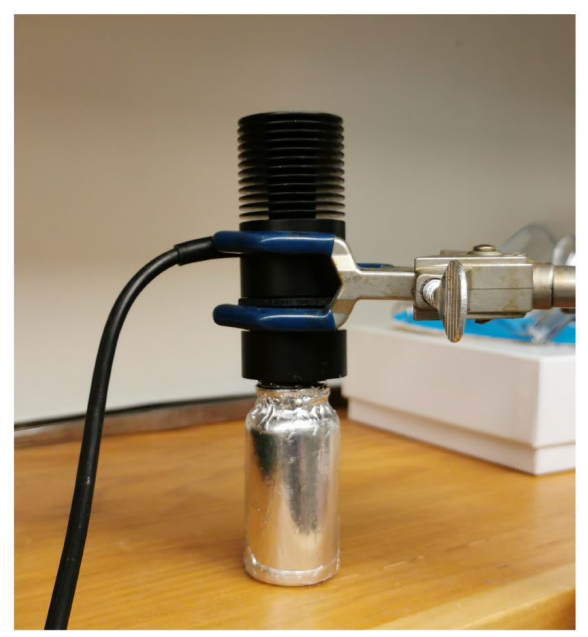

b

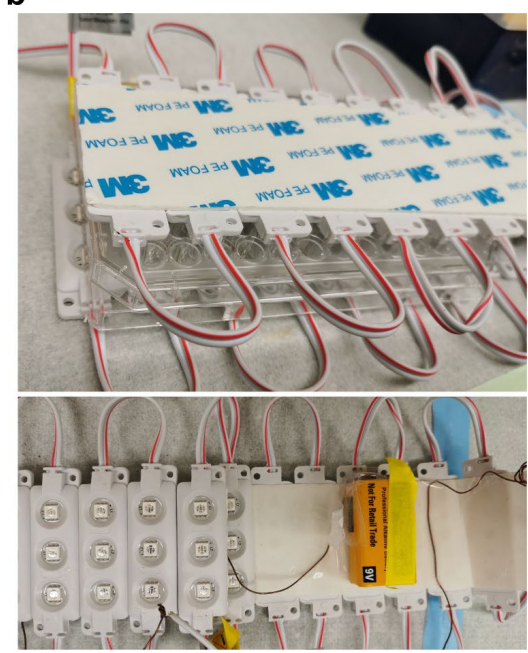

C

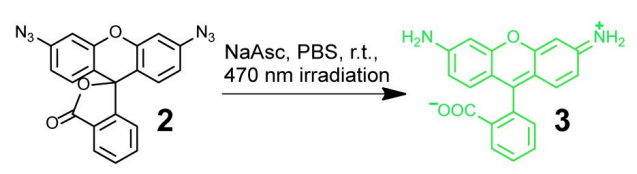

\begin{tabular}{cccc}
\hline RuSCNP & NaAsc & Irradiation & Conversion \\
\hline $\boldsymbol{t}$ & $\boldsymbol{t}$ & $\boldsymbol{+}$ & $>97 \%$ \\
$\boldsymbol{t}$ & $\boldsymbol{-}$ & $\boldsymbol{+}$ & $<1 \%$ \\
$\boldsymbol{t}$ & $\boldsymbol{t}$ & - & $<1 \%$ \\
$\boldsymbol{t}$ & $\boldsymbol{t}$ & $\boldsymbol{+}$ & $<1 \%$ \\
\hline
\end{tabular}

Figure S2. (a) reaction setup when conducted extracellularly. Light source: M470L3 (LED). (b) reaction setup when conducted intracellularly in 96 wells plates. Light source: Injection 3 LED Module Blue $5050 \mathrm{SMD} 0.72 \mathrm{~W}$ (at $12 \mathrm{~V}$ ) powdered by a $9 \mathrm{~V}$ battery. (c) reaction conversions in different contents. $[\mathrm{RuSCNP}]=50 \mathrm{nM},[2]=5 \mu \mathrm{M},[\mathrm{NaAsc}]=2 \mathrm{mM}$. Irradiated at $470 \mathrm{~nm}$ for $10 \mathrm{~min}$. 


\section{RuSCNP cell uptake}

In Ibidi $\mu$-Dish $35 \mathrm{~mm}$ high dishes, $360000 \mathrm{HeLa}$ cells in $3 \mathrm{~mL}$ of DMEM media (10\% FBS added) was added to each dish. The cells were incubated at $37{ }^{\circ} \mathrm{C}$ with $5 \%$ of $\mathrm{CO}_{2}$ for $24 \mathrm{~h}$. The cell media were removed, and each dish was washed three times with $3 \mathrm{~mL}$ of PBS buffer $(1 \mathrm{X}, \mathrm{pH}=7.4)$. To each dish was added $3 \mathrm{~mL}$ of DMEM media without FBS containing $200 \mathrm{nM}$ of RuSCNP, and the cells were incubated at $37{ }^{\circ} \mathrm{C}$ with $5 \%$ of $\mathrm{CO}_{2}$ for $4 \mathrm{~h}$. The cell media were removed, and each dish was washed three times with $3 \mathrm{~mL}$ of PBS buffer (1X, $\mathrm{pH}=7.4)$. To each dish was added $3 \mathrm{~mL}$ of DMEM media containing $50 \mathrm{nM}$ of LysoTracker Green, and the cells were incubated at $37{ }^{\circ} \mathrm{C}$ with $5 \%$ of $\mathrm{CO}_{2}$ for $30 \mathrm{~min}$. The solution was removed, and each dish was washed three times with $3 \mathrm{~mL}$ of PBS buffer $(1 \mathrm{X}, \mathrm{pH}=7.4)$. The cells were imaged by confocal microscopy in the dish. Microscopy conditions are as follows. Laser line: $488 \mathrm{~nm}$, green channel: $500-550 \mathrm{~nm}$, red channel: $600-700 \mathrm{~nm}$. The co-localization between the red emission of RuSCNP and green emission of LysoTracker indicates the nanoparticles enter cells mainly through endocytosis.

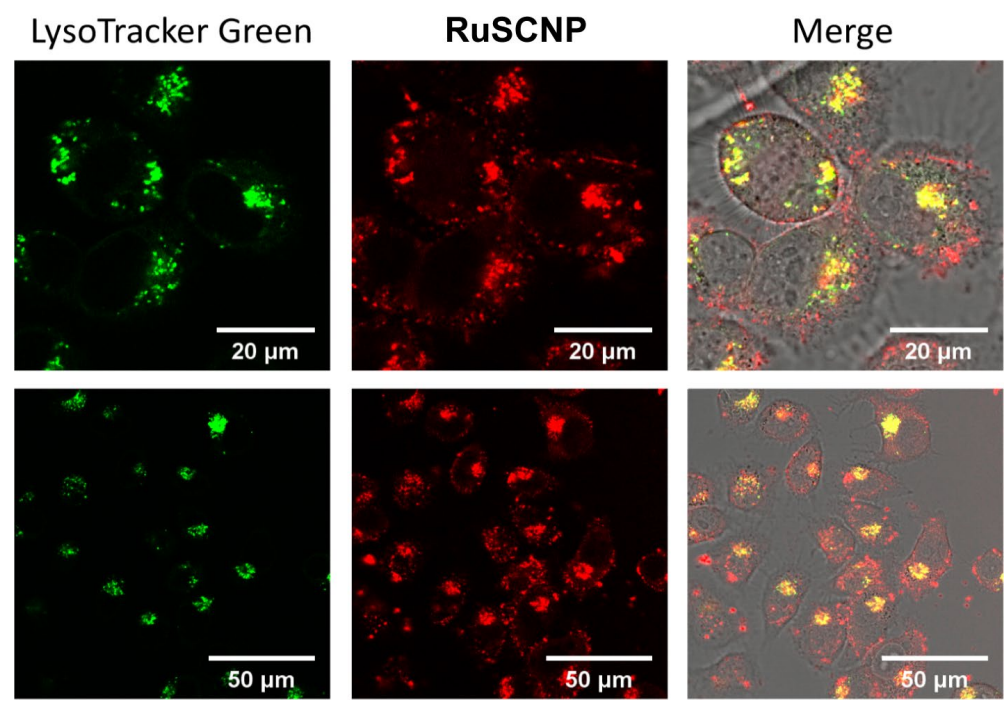

Figure S3. Confocal images of HeLa treated with RuSCNP (200 nM) and LysoTracker Green (50 nM). 


\section{RuSCNP intracellular photoreduction}

For confocal images. In Ibidi $\mu$-Dish $35 \mathrm{~mm}$ high dishes, $360000 \mathrm{HeLa}$ cells in $3 \mathrm{~mL}$ of DMEM media $\left(10 \%\right.$ FBS added) was added to each dish, and the cells were incubated at $37{ }^{\circ} \mathrm{C}$ with $5 \% \mathrm{CO}_{2}$ for $24 \mathrm{~h}$. The cell media were removed, and each well was washed three times with $3 \mathrm{~mL}$ of PBS buffer. To each dish was added $5 \mathrm{~mL}$ of DMEM media containing $200 \mathrm{nM}$ of RuSCNP, and the cells were incubated at $37{ }^{\circ} \mathrm{C}$ with $5 \%$ of $\mathrm{CO}_{2}$ for $4 \mathrm{~h}$. The cell media were removed, and each dish was washed three times with $3 \mathrm{~mL}$ of PBS buffer ( $1 \mathrm{X}, \mathrm{pH}=7.4)$. To each dish was added $1 \mathrm{~mL}$ of PBS buffer $(1 \mathrm{X}, \mathrm{pH}=7.4)$ containing $2 \%$ DMSO and $20 \mu \mathrm{M}$ of 2 . The cells were irradiated with $470 \mathrm{~nm}$ light generated by M470L 3 at $1 \mathrm{~A}$ for $5 \mathrm{~min}$. The cells were imaged by confocal microscopy in the dish. Microscopy conditions are as follows. Laser line: $488 \mathrm{~nm}$, green channel: 500-550 nm, red channel: 600-700 nm.

Flow cytometry. In a 6 wells plate, $600000 \mathrm{HeLa}$ cells were added to each well with $5 \mathrm{~mL}$ of DMEM (10\% FBS), and the cells were incubated at $37{ }^{\circ} \mathrm{C}$ with $5 \% \mathrm{CO}_{2}$ for $24 \mathrm{~h}$. The cell media were removed, and each well was washed three times with $3 \mathrm{~mL}$ of PBS buffer. To each well was added $5 \mathrm{~mL}$ of DMEM media (no FBS) containing $200 \mathrm{nM}$ of RuSCNP, and the cells were incubated at $37{ }^{\circ} \mathrm{C}$ with $5 \% \mathrm{of} \mathrm{CO}_{2}$ for $4 \mathrm{~h}$. The cell media were removed, and each well was washed three times with $3 \mathrm{~mL}$ of PBS buffer $(1 \mathrm{X}, \mathrm{pH}=7.4)$. The cells were detached through trypsinization, and the trypsin was neutralized by adding DMEM media $(10 \%$ FBS). The cell media were removed by using centrifugation, and the cells were resuspended in $1 \mathrm{~mL}$ of PBS buffer ( $1 \mathrm{X}, \mathrm{pH}=7.4)$ containing $2 \%$ DMSO and $20 \mu \mathrm{M}$ of 2 . The cells were irradiated with 470 $\mathrm{nm}$ light generated by M470L3 at $1 \mathrm{~A}$ for 1, 2, 5, $10 \mathrm{~min}$. The fluorescence of the cells was measured by flow cytometry under FITC and Alexa 648 channels.
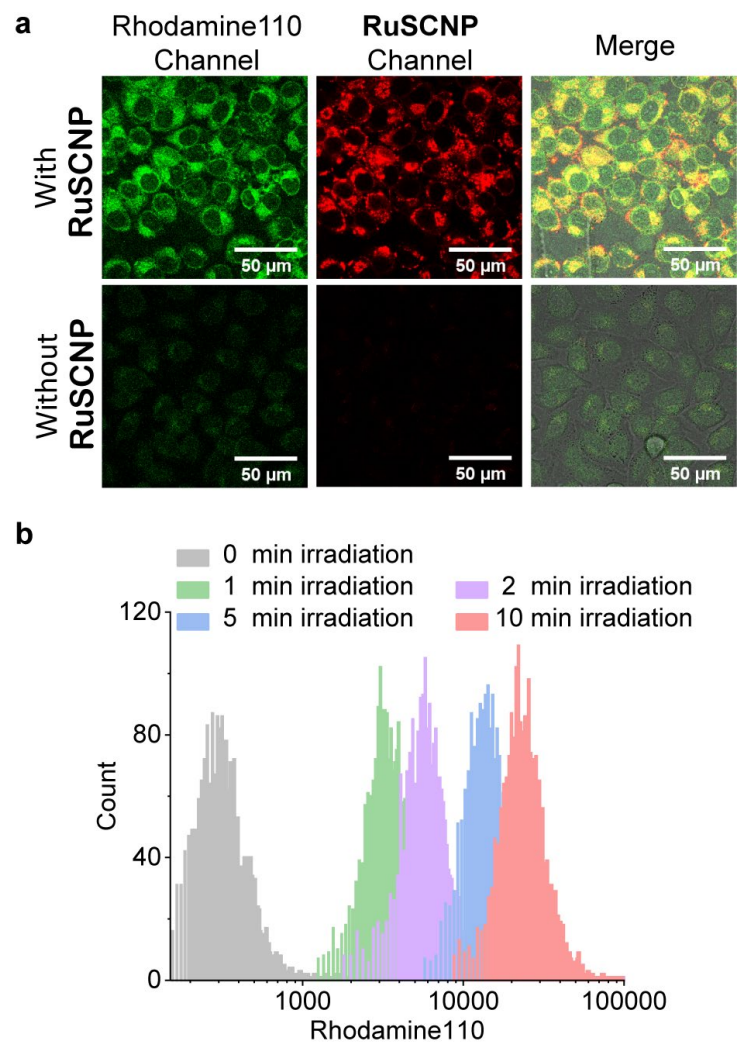

Figure S4. (a) the confocal images of HeLa cells irradiated at $470 \mathrm{~nm}$ with/without RuSCNP (200 nM). (b) the flow cytometry counting of HeLa cells irradiated at $470 \mathrm{~nm}$ for different times with RuSCNP $(200 \mathrm{nM})$ and $2(20 \mu \mathrm{M})$. 


\section{Cell Viability Assay}

In a 96-wells plate, 10000 of HeLa cells in $0.1 \mathrm{~mL}$ of DMEM media (10\% FBS) was added to each well and incubated at $37{ }^{\circ} \mathrm{C}$ with $5 \% \mathrm{CO}_{2}$ for $24 \mathrm{~h}$. The cell media were removed, and each well was washed three times with $100 \mu \mathrm{L}$ of PBS buffer $(1 \mathrm{x}, \mathrm{pH}=7.4)$. To each well was added $100 \mu \mathrm{L}$ of DMEM media without FBS containing 0, 50, 100, 200, 400, $800 \mathrm{nM}$ of RuSCNP, and the cells were incubated at $37^{\circ} \mathrm{C}$ with $5 \% \mathrm{CO}_{2}$ for $4 \mathrm{~h}$. The cell media were removed, and each well was washed 3 times with $100 \mu \mathrm{L}$ of PBS buffer $(1 \mathrm{x}, \mathrm{pH}=7.4)$. The cells in each well in $100 \mu \mathrm{L}$ of PBS buffer was treated with/without irradiation at $470 \mathrm{~nm}$ for $10 \mathrm{~min}$. The PBS buffer was removed, and the cells were incubated with DMEM media (10\% FBS) for $1 \mathrm{~h}$ and the cell viability was measured through MTT assay (Figure S5a). For long-term toxicity, the experiments were conducted by incubating cells with RuSCNP or SCNP for $24 \mathrm{~h}$ under the same conditions (Figure S5b).

a
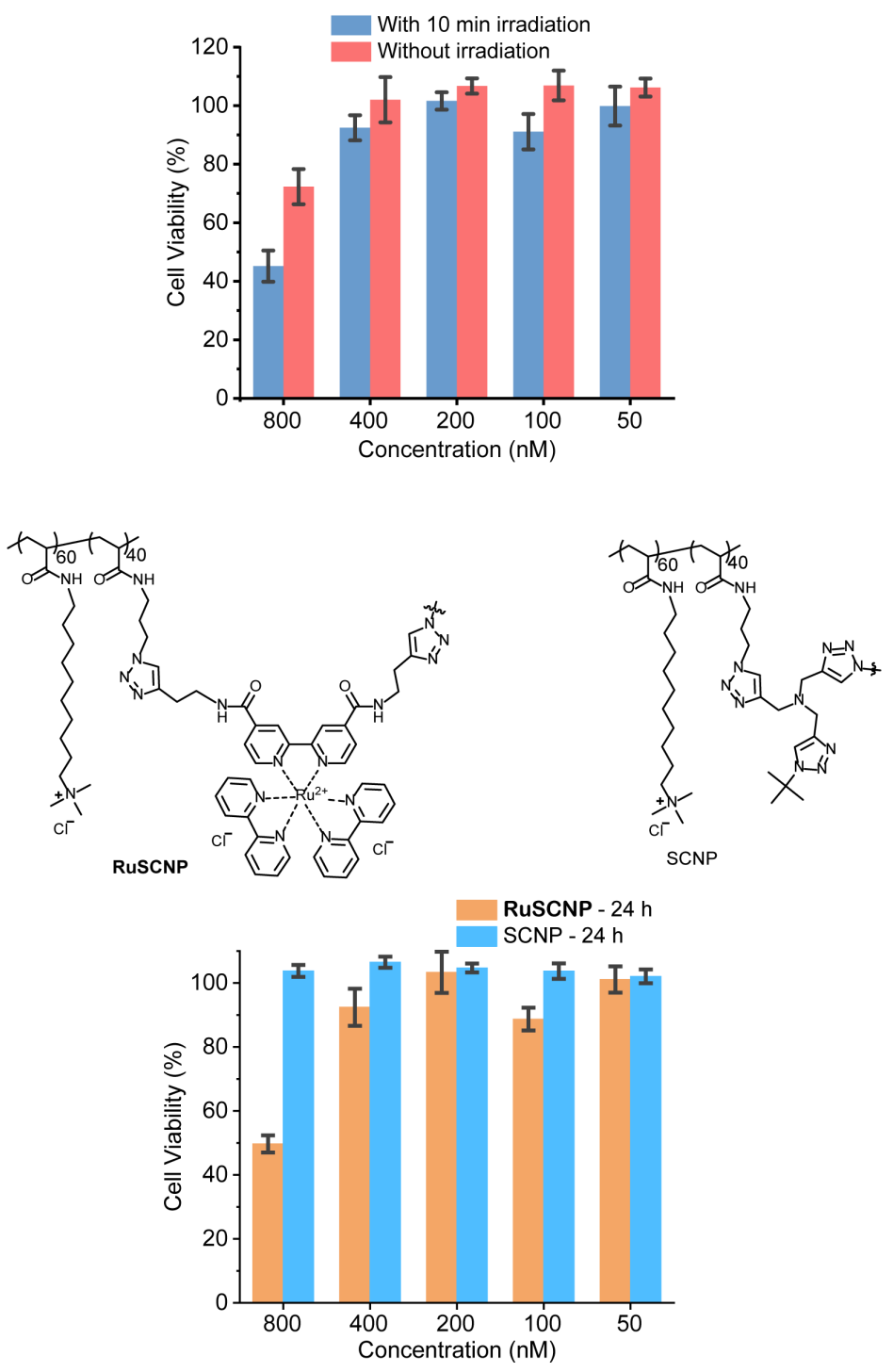

Figure S5. (a) cell viability of HeLa cells after treating with different concentrations of RuSCNP with/without irradiation under reaction condition ( $4 \mathrm{~h}$ incubation). (b) $24 \mathrm{~h}$ toxicity of RuSCNP and SCNP at different concentration. 


\section{RuSCNP retention in HeLa cells}

In a 6 wells plate, 600000 HeLa cells were added to each well with $5 \mathrm{~mL}$ of DMEM $(10 \% \mathrm{FBS})$, and the cells were incubated at $37{ }^{\circ} \mathrm{C}$ with $5 \% \mathrm{CO}_{2}$ for $24 \mathrm{~h}$. The cell media were removed, and each well was washed three times with $3 \mathrm{~mL}$ of PBS buffer. To each well was added $5 \mathrm{~mL}$ of DMEM media (no FBS) containing $200 \mathrm{nM}$ of RuSCNP, and the cells were incubated at $37{ }^{\circ} \mathrm{C}$ with $5 \%$ of $\mathrm{CO}_{2}$ for $4 \mathrm{~h}$. The cell media were removed, and each well was washed three times with $3 \mathrm{~mL}$ of PBS buffer $(1 \mathrm{X}, \mathrm{pH}=7.4)$. The cells were detached through trypsinization, and the trypsin was neutralized by adding DMEM media (10\% FBS). The cell media were removed by using centrifugation, and the cells were washed three times with 1 $\mathrm{mL}$ of PBS buffer $(1 \mathrm{X}, \mathrm{pH}=7.4)$. The solutions were separated from the cells and combined. The combined solution was measured by fluorimeter, and almost no emission of RuSCNP was observed (Figure S6a).

\section{Intracellular reaction with/without adding NaAsc}

Under the same conditions for flow cytometry measured intracellular photoreduction, the cells were suspended in $1 \mathrm{~mL}$ of PBS buffer $(1 \mathrm{X}, \mathrm{pH}=7.4)$ containing $2 \%$ DMSO and $20 \mu \mathrm{M}$ of 2 with/without 2 $\mathrm{mM}$ of NaAsc. The cells were irradiated with $470 \mathrm{~nm}$ light generated by M470L3 at $1 \mathrm{~A}$ for 1, 2, 5, $10 \mathrm{~min}$. The fluorescence of the cells was measured by flow cytometry under FITC and Alexa 648 channels. The average fluorescence intensities from the FITC channel were calculated and presented in Figure S6b. No significant difference was observed with/without adding NaAsc.

\section{Background azido-rhodamine reduction}

In Ibidi $\mu$-Dish $35 \mathrm{~mm}$ high dishes, $360000 \mathrm{HeLa}$ cells in $3 \mathrm{~mL}$ of DMEM media (10\% FBS added) was added to each dish, and the cells were incubated at $37{ }^{\circ} \mathrm{C}$ with $5 \% \mathrm{CO}_{2}$ for $24 \mathrm{~h}$. To each dish was added 1 $\mathrm{mL}$ of DMEM media containing $2 \%$ DMSO and $20 \mu \mathrm{M}$ of 2 . The cells were incubated for $2 \mathrm{~h}$ or $24 \mathrm{~h}$ and imaged by confocal microscopy at green channel: 500-550 nm (Figure S6c).

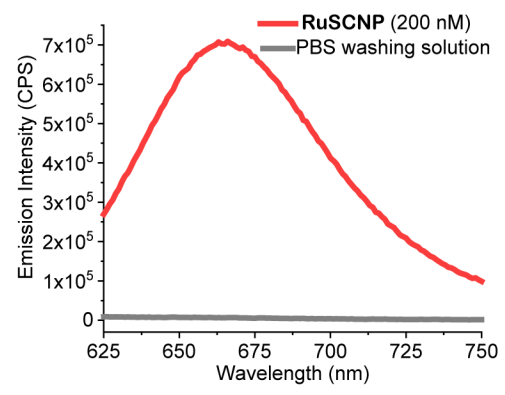

b

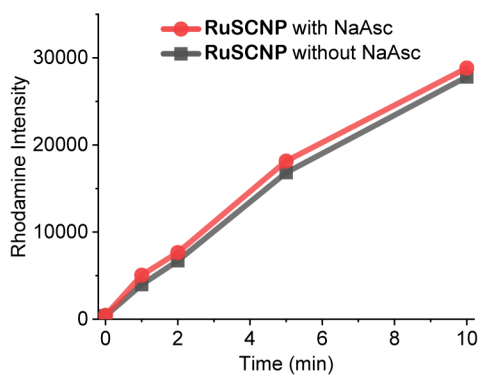

C

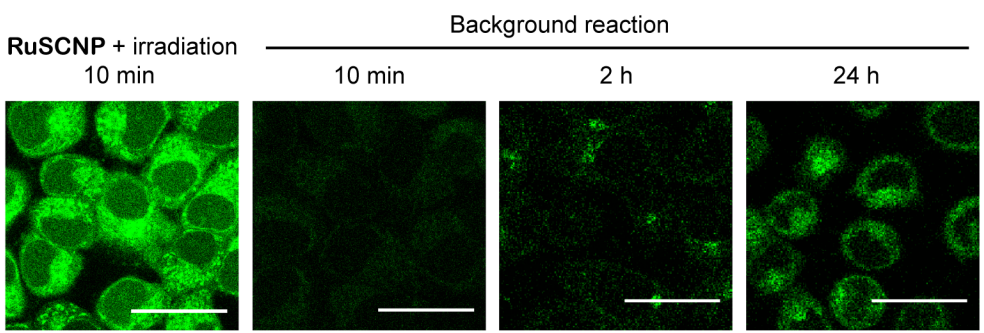

Figure S6. (a) emission spectra of RuSCNP (200 nM) in PBS buffer and the PBS washing solution. (b) The average fluorescence intensities of HeLa cells with/without adding NaAsc during intracellular photoreduction. The intensities were calculated from the FITC channel measured by flow cytometry. (c) confocal images of HeLa cells with 2 for studying the long-term background reaction. 


\title{
RuSCNP-BGal Dual Catalysis
}

\begin{abstract}
Preparation of HeLa cell lysate
To HeLa cells in T175 flask at $80-90 \%$ confluency, cells were detached by trypsinization and centrifuged down for $5 \mathrm{~min}$ at $1000 \mathrm{~g}$ at $4{ }^{\circ} \mathrm{C}$. The cell pellets were washed twice with $10 \mathrm{~mL}$ of PBS buffer $(1 \mathrm{x}, \mathrm{pH}=$ 7.4 ), and resuspended in $10 \mathrm{~mL}$ of $1 \% \mathrm{NP}-40$ lysis buffer $(1 \% \mathrm{NP}-40,150 \mathrm{mM}$ of NaCl, $50 \mathrm{mM}$ of triethanolamine, $\mathrm{pH}=7.4$, with 1 tablet of Complete, Mini EDTA-free Protease Inhibitor Cocktail Tablet Roche] for $20 \mathrm{~min}$, and the suspension was centrifuged at $10000 \mathrm{~g}$ for $10 \mathrm{~min}$ at $4^{\circ} \mathrm{C}$. The supernatant was filtered through a $0.45 \mu \mathrm{m}$ to afford the HeLa cell lysate.
\end{abstract}

\section{RuSCNP- $\beta$ Gal dual catalysis in cell lysate}

In a $20 \mathrm{~mL}$ glass vial covered by aluminum foil, the catalyst, 2,4 and NaAsc were added to $1 \mathrm{~mL}$ of HeLa cell lysate. The final concentrations were: $[2]=20 \mu \mathrm{M},[\mathbf{4}]=100 \mu \mathrm{M},[\mathbf{R u S C N P}]=200 \mathrm{nM},[\beta \mathrm{Gal}]=20$ $\mathrm{nM}$ and $[\mathrm{NaAsc}]=2 \mathrm{mM}$. The vial was irradiated by M470L3 at $1 \mathrm{~A}$ for $10 \mathrm{~min}$. After irradiation the solution was diluted 100 times in PBS buffer in a $4 \mathrm{~mL}$ quartz cuvette and measured by a fluorometer. For product 3, ex: $490 \mathrm{~nm}$, em: $521 \mathrm{~nm}$. For product 5, ex: $340 \mathrm{~nm}$, em $445 \mathrm{~nm}$. The conversions were determined by using pure $\mathbf{3}$ and $\mathbf{5}$ as the standard.

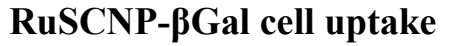 \\ RuSCNP+ $\boldsymbol{\beta}$ GalF. In Ibidi $\mu$-Dish $35 \mathrm{~mm}$ high dishes, $360000 \mathrm{HeLa}$ cells in $3 \mathrm{~mL}$ of DMEM media $(10 \%$ FBS added) was added to each dish. The cells were incubated at $37{ }^{\circ} \mathrm{C}$ with $5 \%$ of $\mathrm{CO}_{2}$ for $24 \mathrm{~h}$. The cell media were removed, and each dish was washed three times with $3 \mathrm{~mL}$ of PBS buffer $(1 \mathrm{X}, \mathrm{pH}=7.4)$. To each dish was added $3 \mathrm{~mL}$ of DMEM media without FBS containing 2\% DMSO, $200 \mathrm{nM}$ of RuSCNP and $20 \mathrm{nM}$ of $\beta \mathrm{GalF}$, and the cells were incubated at $37{ }^{\circ} \mathrm{C}$ with $5 \%$ of $\mathrm{CO}_{2}$ for $4 \mathrm{~h}$. The cell media were removed, and each dish was washed three times with $3 \mathrm{~mL}$ of PBS buffer $(1 \mathrm{X}, \mathrm{pH}=7.4)$. The cells were imaged by confocal microscopy in the dish. Microscopy conditions are as follows. Laser line: $488 \mathrm{~nm}$, green channel: $500-550 \mathrm{~nm}$, red channel: $600-700 \mathrm{~nm}$. The co-localization between the red emission of RuSCNP and green emission of $\beta$ GalF indicates the nanoparticles delivered the enzyme into the cells.}

RuSCNP+ßGGal+LysoTracker. In Ibidi u-Dish $35 \mathrm{~mm}$ high dishes, $360000 \mathrm{HeLa}$ cells in $3 \mathrm{~mL}$ of DMEM media (10\% FBS added) was added to each dish. The cells were incubated at $37{ }^{\circ} \mathrm{C}$ with $5 \%$ of $\mathrm{CO}_{2}$ for 24 $\mathrm{h}$. The cell media were removed, and each dish was washed three times with $3 \mathrm{~mL}$ of PBS buffer (1X, $\mathrm{pH}$ $=7.4$ ). To each dish was added $3 \mathrm{~mL}$ of DMEM media without FBS containing 2\% DMSO, $200 \mathrm{nM}$ of RuSCNP and $20 \mathrm{nM}$ of $\beta \mathrm{Gal}$, and the cells were incubated at $37{ }^{\circ} \mathrm{C}$ with $5 \%$ of $\mathrm{CO}_{2}$ for $4 \mathrm{~h}$. The cell media were removed, and each dish was washed three times with $3 \mathrm{~mL}$ of PBS buffer $(1 \mathrm{X}, \mathrm{pH}=7.4)$. To each dish was added $3 \mathrm{~mL}$ of DMEM media containing $50 \mathrm{nM}$ of LysoTracker Green, and the cells were incubated at $37{ }^{\circ} \mathrm{C}$ with $5 \%$ of $\mathrm{CO}_{2}$ for $30 \mathrm{~min}$. The solution was removed, and each dish was washed three times with $3 \mathrm{~mL}$ of PBS buffer $(1 \mathrm{X}, \mathrm{pH}=7.4)$. The cells were imaged by confocal microscopy in the dish. Microscopy conditions are as follows. Laser line: $488 \mathrm{~nm}$, green channel: 500-550 nm, red channel: 600$700 \mathrm{~nm}$. The co-localization between the red emission of RuSCNP and green emission of LysoTracker indicates the nanoparticles and enzymes enter cells mainly through endocytosis and stay in the endosomes (Figure S7). 
(a)
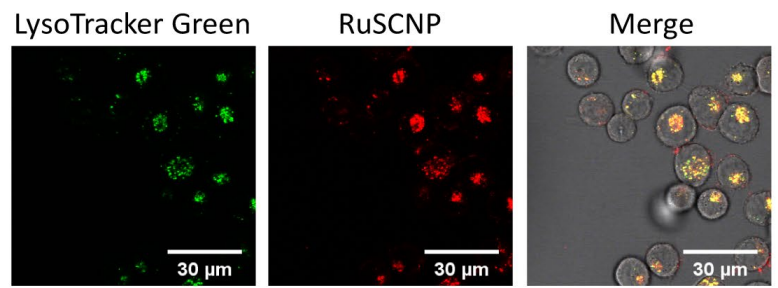

(b)

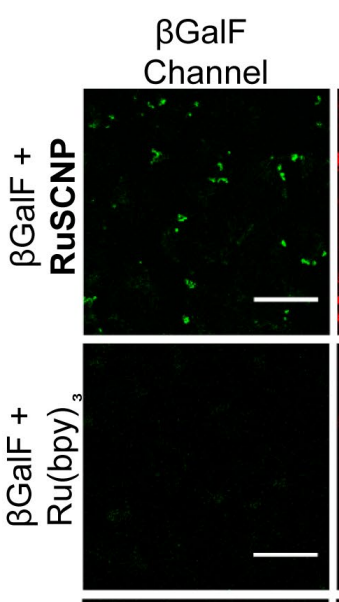

\section{RuSCNP \\ Channel}
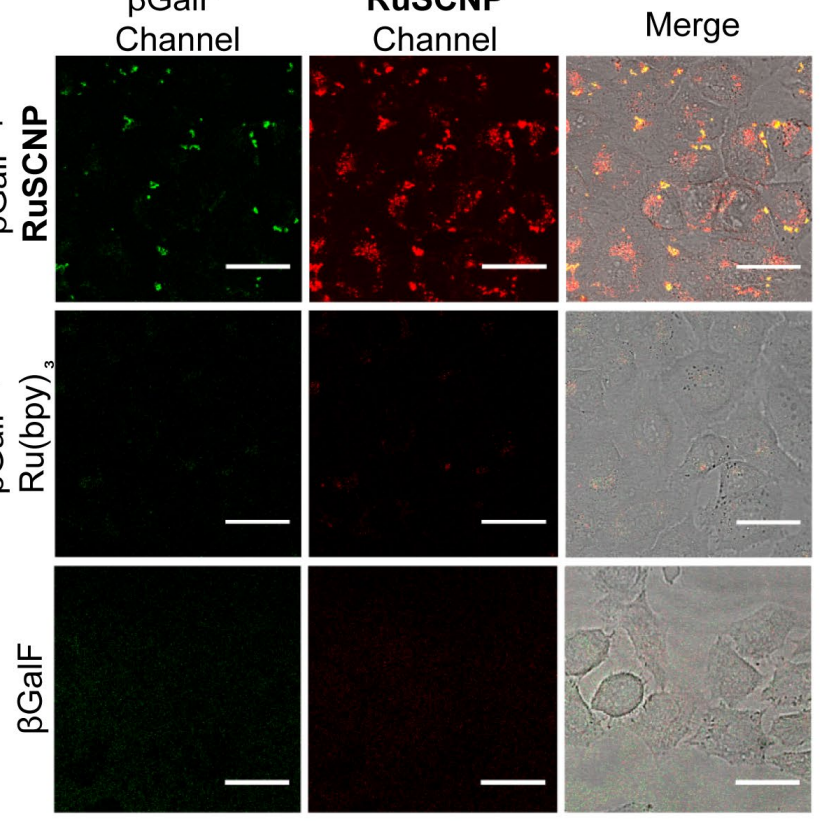

(c)
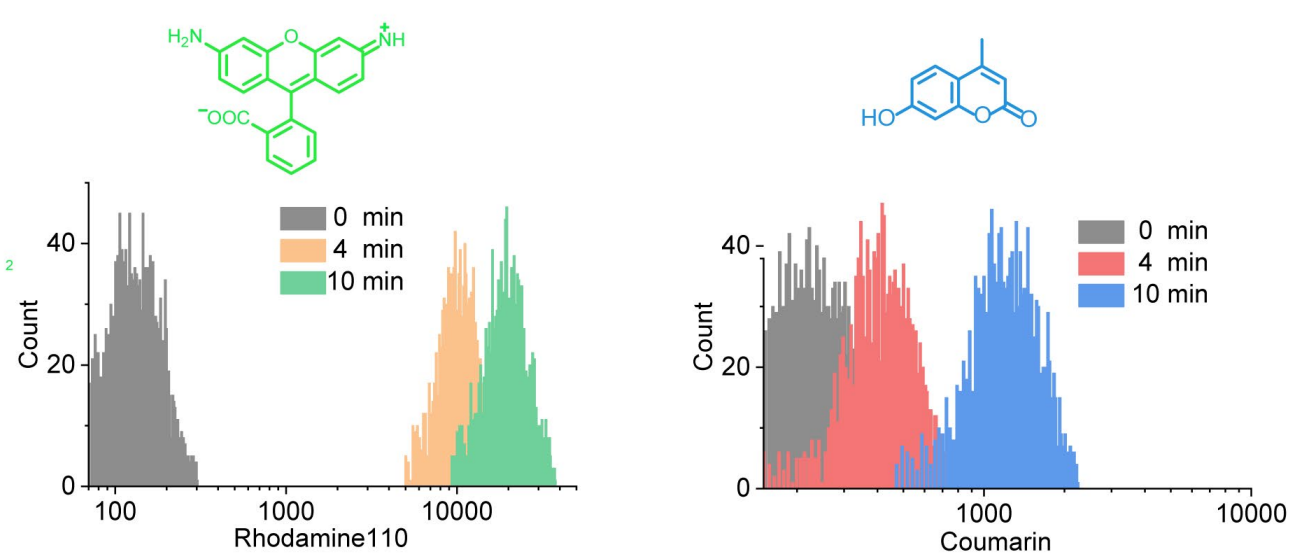

Figure S7. (a) confocal images of HeLa treated with RuSCNP (200 nM), $\beta$ Gal $(20 \mathrm{nM})$ and LysoTracker Green $(50 \mathrm{nM})$. (b) confocal images of HeLa cells treated with $\beta \mathrm{GalF}(20 \mathrm{nM})$ with or without RuSCNP $(200 \mathrm{nM})$ or Ru(bpy $)_{3}(4 \mu \mathrm{M})$ for $4 \mathrm{~h}$. scale bar $=30 \mu \mathrm{m}$. (c) flow-cytometry of HeLa cells treated with $2(20 \mu \mathrm{M}), \mathbf{3}(100 \mu \mathrm{M})$ and RuSCNP $(200 \mathrm{nM})$. 


\section{RuSCNP- $\beta$ Gal dual catalysis inside cells}

For confocal images. In Ibidi $\mu$-Dish $35 \mathrm{~mm}$ high dishes, $360000 \mathrm{HeLa}$ cells in $3 \mathrm{~mL}$ of DMEM media $\left(10 \% \mathrm{FBS}\right.$ added) was added to each dish, and the cells were incubated at $37{ }^{\circ} \mathrm{C}$ with $5 \% \mathrm{CO}_{2}$ for $24 \mathrm{~h}$. The cell media were removed, and each well was washed three times with $3 \mathrm{~mL}$ of PBS buffer. To each dish was added $5 \mathrm{~mL}$ of DMEM media containing $20 \mathrm{nM}$ of $\beta \mathrm{Gal}$ with/without $200 \mathrm{nM}$ of RuSCNP or $4 \mu \mathrm{M}$ of $\mathrm{Ru}(\text { bpy })_{3}$, and the cells were incubated at $37^{\circ} \mathrm{C}$ with $5 \%$ of $\mathrm{CO}_{2}$ for $4 \mathrm{~h}$. The cell media were removed, and each dish was washed three times with $3 \mathrm{~mL}$ of PBS buffer $(1 \mathrm{X}, \mathrm{pH}=7.4)$. To each dish was added 1 $\mathrm{mL}$ of PBS buffer $(1 \mathrm{X}, \mathrm{pH}=7.4)$ containing $4 \%$ DMSO, $20 \mu \mathrm{M}$ of 2 and $100 \mu \mathrm{M}$ of 4 . The cells were irradiated with $470 \mathrm{~nm}$ light generated by M470L3 at $1 \mathrm{~A}$ for $10 \mathrm{~min}$. The cells were imaged by confocal microscopy in the dish. Microscopy conditions are as follows. Laser line: 405 and $488 \mathrm{~nm}$, blue channel: 425-475 nm, green channel: 500-550 nm, red channel: 600-700 nm.

For flow cytometry. In a 6 wells plate, $600000 \mathrm{HeLa}$ cells were added to each well with $5 \mathrm{~mL}$ of DMEM $(10 \%$ FBS $)$, and the cells were incubated at $37^{\circ} \mathrm{C}$ with $5 \% \mathrm{CO}_{2}$ for $24 \mathrm{~h}$. The cell media were removed, and each well was washed three times with $3 \mathrm{~mL}$ of PBS buffer. To each well was added $5 \mathrm{~mL}$ of DMEM media (no FBS) containing $20 \mathrm{nM}$ of $\beta \mathrm{Gal}$ with $200 \mathrm{nM}$ of RuSCNP or $4 \mu \mathrm{M}$ of $\mathrm{Ru}(\mathrm{bpy})_{3}$, and the cells were incubated at $37{ }^{\circ} \mathrm{C}$ with $5 \%$ of $\mathrm{CO}_{2}$ for $4 \mathrm{~h}$. The cell media were removed, and each well was washed three times with $3 \mathrm{~mL}$ of PBS buffer $(1 \mathrm{X}, \mathrm{pH}=7.4)$. The cells were detached through trypsinization, and the trypsin was neutralized by adding DMEM media (10\% FBS). The cell media were removed by using centrifugation, and the cells were resuspended in $1 \mathrm{~mL}$ of PBS buffer $(1 \mathrm{X}, \mathrm{pH}=7.4)$ containing $4 \%$ DMSO, $20 \mu \mathrm{M}$ of 2 and $100 \mu \mathrm{M}$ of 4 . The cells were irradiated with $470 \mathrm{~nm}$ light generated by M470L3 at $1 \mathrm{~A}$ for 4 or $10 \mathrm{~min}$. The fluorescence of the cells was measured by flow cytometry under pacific blue, FITC and Alexa 648 channels. The average fluorescence increases for substrates 4 and 2 were calculated from the pacific blue and FITC channels, suggesting almost no reaction with Ru(bpy) 3 and $\beta \mathrm{Gal}$ (Figure S8).

a
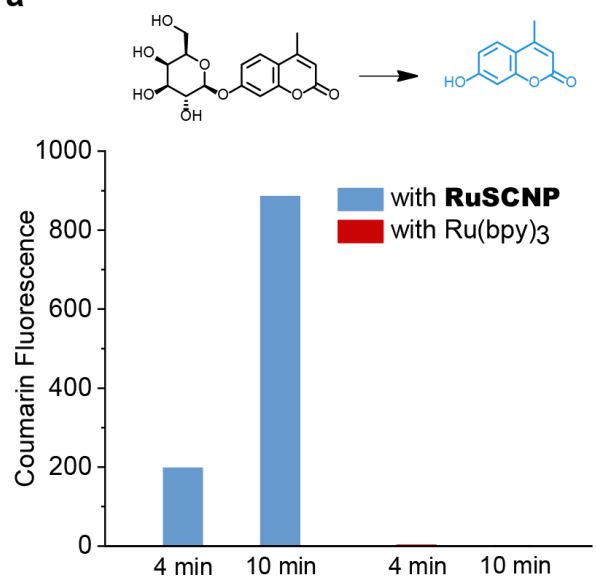

b

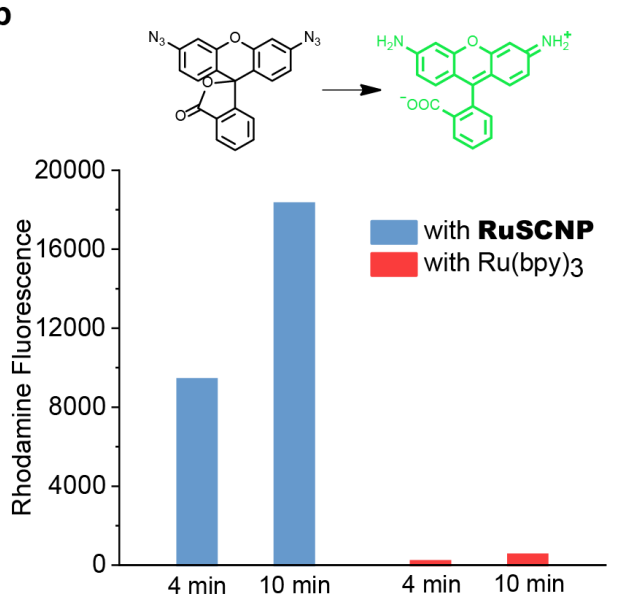

Figure S8. The average fluorescence increases with substrates $\mathbf{4}$ and $\mathbf{2}$. 


\section{Quantification of the intracellular reactions}

In a T75 cell flask, HeLa cells were grown to $100 \%$ confluency. The cell media were removed, and the cells were washed three times with PBS buffer. To the flask was added $20 \mathrm{~mL}$ of DMEM containing $200 \mathrm{nM}$ of RuSCNP and $20 \mathrm{nM}$ of beta-galactosidase, and the cells were incubated at $37{ }^{\circ} \mathrm{C}$ for $4 \mathrm{~h}$. The solution was removed, and the cells were washed three times with PBS buffer and detached through trypsinization. The trypsin was neutralized by DMEM media (10\% FBS), and the cell media were removed by using centrifugation. The cells were resuspended in $2 \mathrm{~mL}$ of PBS buffer containing $2 \%$ DMSO, $20 \mu \mathrm{M}$ of 2 and $100 \mu \mathrm{M}$ 4. The cell suspension was transferred to glass vial and irradiated with $470 \mathrm{~nm}$ light generated by M470L3 at $1 \mathrm{~A}$ for $10 \mathrm{~min}$. The suspension was centrifuged at $500 \mathrm{~g}$ for $5 \mathrm{~min}$, and the supernatant was removed. The cells were resuspended in $1 \mathrm{~mL}$ of $1 \% \mathrm{NP}-40$ lysis buffer $(1 \% \mathrm{NP}-40,150 \mathrm{mM} \mathrm{NaCl}, 50 \mathrm{mM}$ triethanolamine, $\mathrm{pH}=7.4$ for $20 \mathrm{~min}$, and the suspension was centrifuged at $13300 \mathrm{~g}$ for $20 \mathrm{~min}$ at $4^{\circ} \mathrm{C}$. The supernatant was analyzed as the cell lysate.

\section{Quantification by using the fluorimeter}

For the azide reduction on 2: in a $0.7 \mathrm{~mL}$ cuvette for the fluorimeter, the cell lysate was diluted 100 times in $0.5 \mathrm{~mL}$ of PBS buffer, and the fluorescence spectrum was measured (ex: $485 \mathrm{~nm}$, em: $521 \mathrm{~nm}$ ). To the solution was added $25 \mu \mathrm{L}$ of $1 \mathrm{mM}$ triphenylphosphine $\left(\mathrm{PPh}_{3}\right)$ solution in DMSO (in excess), and the fluorescence spectra were measured $60 \mathrm{~min}$ after the addition under the same condition which presumably reduced all of the compound $\mathbf{2}$. The conversion was calculated by comparing the fluorescence intensity before and after the addition of $\mathrm{PPh}_{3}$.

For the cleavage reaction on $4:$ in a $0.7 \mathrm{~mL}$ cuvette for the fluorimeter, the cell lysate was diluted 100 times in $0.5 \mathrm{~mL}$ of PBS buffer, and the fluorescence spectrum was measured (ex: $340 \mathrm{~nm}$, em: $445 \mathrm{~nm}$ ). To the solution was added $5 \mu \mathrm{L}$ of $4 \mu \mathrm{M}$ beta-Gal solution in PBS buffer (sufficient to hydrolyze all of the compound 4), and the fluorescence spectra were measured $60 \mathrm{~min}$ after the addition under the same condition. The conversion was calculated by comparing the fluorescence intensity before and after the addition of extra $\beta \mathrm{Gal}$.

\section{Quantification by using the HPLC}

The cell lysate was transferred to an Amicon tube with $10 \mathrm{kDa}$ cutoff and centrifuged at $13.3 \mathrm{k} \mathrm{g}$ for $20 \mathrm{~min}$. The solution passed through the membrane was analyzed through HPLC. Injection volume $=100 \mu \mathrm{L}$. Detector: UV absorption at $254 \mathrm{~nm}$. Almost no signals were observed for substrates 2 and $\mathbf{4}$, indicating high conversions of the two reactions. The absolute concentrations of the products were calculated by using standard curves of $\mathbf{3}$ and $\mathbf{5}$. 
a

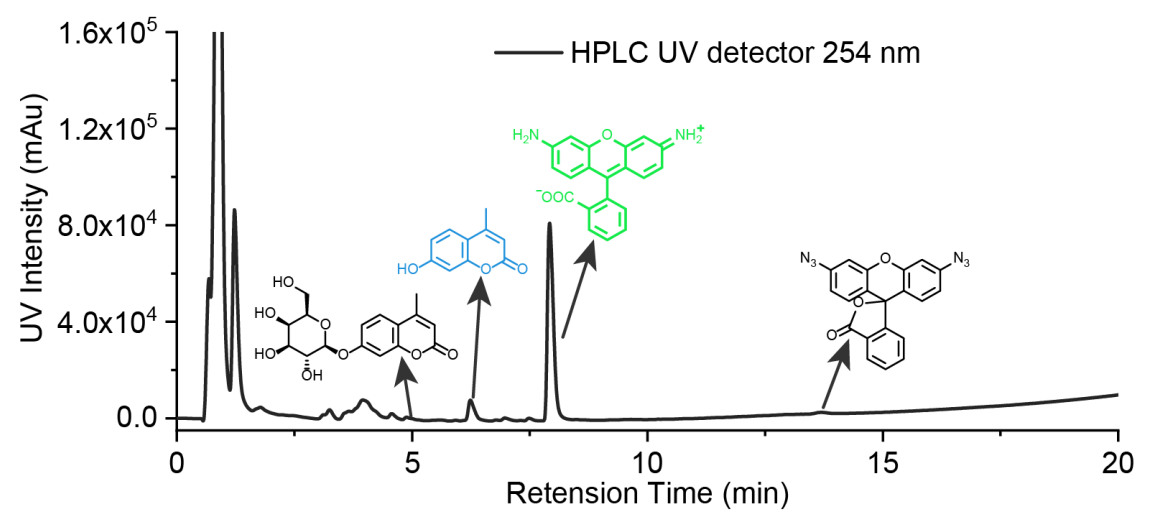

b

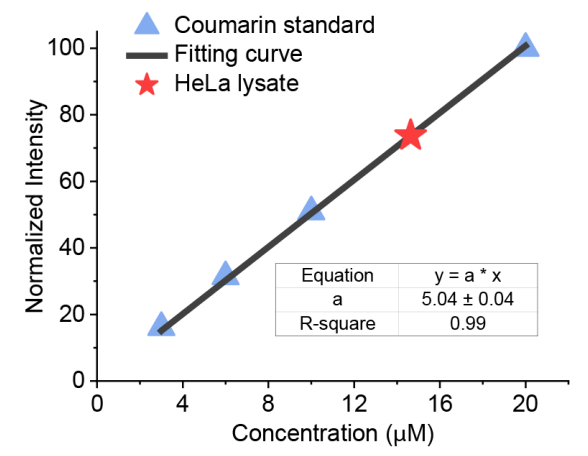

C

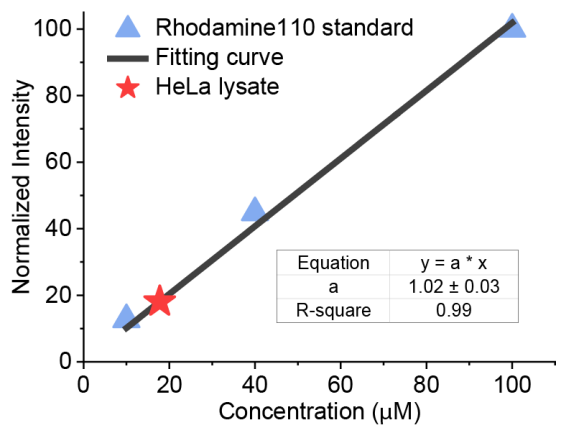

d

\begin{tabular}{|c|c|c|}
\hline & RusCNP Reaction & bGal Reaction \\
\hline Conversion (HPLC) & $>90 \%$ & $>90 \%$ \\
\hline Conversion (Fluorimeter) & $83 \%$ & $94 \%$ \\
\hline Concentration of product & $18 \mu \mathrm{M}$ & $14 \mu \mathrm{M}$ \\
\hline TON & 26 & - \\
\hline
\end{tabular}

Figure S9. Quantification of the intracellular reactions. (a) the HPLC trace of the HeLa cell lysate after the RuSCNP- $\beta$ Gal dual catalysis. (b) the standard curve on the HPLC by using pure 5. (b) the standard curve on the HPLC by using pure 3. (d) conversions and the turnover number of the intracellular reactions. 


\section{Intracellular dual drug activation}

In a 96 wells plate, $20000 \mathrm{HeLa}$ cells were added to each well with $150 \mu \mathrm{L}$ of DMEM media (10\% FBS added), and the cells were incubated at $37{ }^{\circ} \mathrm{C}$ with $5 \% \mathrm{CO}_{2}$ overnight. The cell media were removed, and each well was washed three times with $100 \mu \mathrm{L}$ of PBS buffer. The cells were incubated with RuSCNP (200 $\mathrm{nM})$ and $\beta$ Gal $(20 \mathrm{nM})$ in DMEM media (no FBS) for $4 \mathrm{~h}$. The solution was removed, and each well was washed with PBS buffer for three times. The cells were incubated in DMEM $(10 \%$ FBS $)$ with $6(1 \mu \mathrm{M})$ and $7(4 \mu \mathrm{M})$. After $2 \mathrm{~h}$ incubation, the cells were irradiated at $470 \mathrm{~nm}$ for $5 \mathrm{~min}$ and incubated for another 22 $\mathrm{h}$. The cell viability was measured by MTT assay.

\section{RuSCNP- $\beta$ Gal tandem reaction in HeLa cell lysate}

In a $20 \mathrm{~mL}$ glass vial covered by aluminum foil, RuSCNP, 8 and NaAsc were added to $1 \mathrm{~mL}$ of total volume of HeLa cell lysate. The final concentrations were: $[\mathbf{8}]=20 \mu \mathrm{M},[\mathbf{R u S C N P}]=200 \mathrm{nM},[\beta \mathrm{Gal}]=$ $20 \mathrm{nM}$ and $[\mathrm{NaAsc}]=2 \mathrm{mM}$. The vial was irradiated by M470L3 at $1 \mathrm{~A}$ for $10 \mathrm{~min}$. After irradiation the solution was measured by a fluorimeter. Ex: $340 \mathrm{~nm}, \mathrm{Em}$ : $445 \mathrm{~nm}$. The conversion was determined by using the pure $\mathbf{5}$ as the standard.

\section{RuSCNP- $\beta$ Gal tandem reaction in $E$. coli cells}

E.coli cells were grown in LB media at $37{ }^{\circ} \mathrm{C}$ in a shaker overnight. The LB media were removed through centrifugation, and the cells were washed three times with PBS buffer. In separated test tubes, E. coli cells were incubated in M9 media containing $20 \mathrm{nM} \beta \mathrm{Gal}$ with/without $200 \mathrm{nM}$ of RuSCNP at $37^{\circ} \mathrm{C}$ in a shaker for $4 \mathrm{~h}$ starting at $\mathrm{OD}_{600}=0.5$. The cells were washed three times with PBS buffer and incubated with PBS buffer containing $20 \mu \mathrm{M}$ of 8 and $4 \%$ DMSO (v/v) for the intracellular tandem reaction. The cells were irradiated for 5, 10, 15, 20 min and the fluorescence intensity of the product coumarin $\mathbf{5}$ was measured by using flow cytometry.

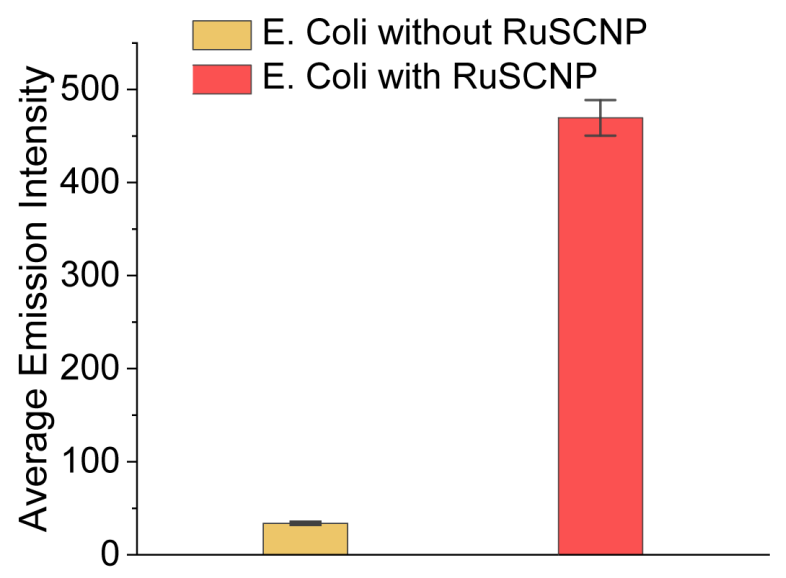

Figure S10. Flow cytometry analysis on the RuSCNP uptake of $E$. coli cells. 


\section{$\underline{\text { RuSCNP-BGal Binding Studies }}$}

\section{Saturation transfer difference (STD) experiment}

The NMR solution was prepared in $0.7 \mathrm{~mL}$ of deuterium oxide PBS buffer $(1 \mathrm{x}, \mathrm{pD}=7.4)$ containing $5 \mu \mathrm{M}$ of $\beta \mathrm{Gal}$ and $50 \mu \mathrm{M}$ of RuSCNP. STD spectra were collected using a water suppression STD method on a VNS750 spectrometer with the bio-pack software. During the saturation period, the alkyl region of $\beta$ Gal was irradiated at $-0.5 \mathrm{ppm}$, with the irradiation time ranging from $0.5 \mathrm{~s}$ to $3 \mathrm{~s}$. To minimize intramolecular signals from $\beta \mathrm{Gal}$, a $15 \mathrm{~ms}$ relaxation $\mathrm{T}_{2}$ filter was applied during data acquisition. Spectra were processed by MestReNova (v. 8.1), and the STD effect intensity was calculated for the aromatic region of RuSCNP at 8.7-7.2 ppm, the trimethyl ammonium peak at $3.0 \mathrm{ppm}$, the alkyl signals around $1.6 \mathrm{ppm}$ and the alkyl chain peak at $1.2 \mathrm{ppm}$ through the equation: $\mathrm{STD}=\left(\mathrm{I}_{0}-\mathrm{I}_{\text {sat }}\right) / \mathrm{I}_{0}$.

\section{Fluorescence polarization experiment}

Fluorescein labelled $\beta \mathrm{Gal}(\beta \mathrm{GalF})$ was dissolved in PBS buffer $(1 \mathrm{x}, \mathrm{pH}=7.4)$ at the concentration of 20 $\mathrm{nM}$ with the concentration of RuSCNP ranging from 0 to $800 \mathrm{nM}$. The solutions were transferred to a black 384-wells plate, and $50 \mu \mathrm{L}$ of the solution was added to each well. The fluorescence polarization of solutions in each well was measured on an Analyst HT plate reader with the setup on fluorescein (ex filter: $485 \pm 10$ $\mathrm{nm}$, em filter: $520 \pm 10 \mathrm{~nm}$ ). The measurement was conducted in the High-throughput Screening Facility, School of Chemical Science, University of Illinois. 


\section{Reference}

1. Sasmal, P. K.; Carregal-Romero, S.; Han, A. A.; Streu, C. N.; Lin, Z.; Namikawa, K.; Elliott, S. L.; Köster, R. W.; Parak, W. J.; Meggers, E., Catalytic Azide Reduction in Biological Environments. ChemBioChem, 2012, 13, 1116-1120.

2. Brakel, R. v.; Vulders, R. C. M.; Bokdam, R. J.; Grüll, H.; Robillard, M. S., A Doxorubicin Prodrug Activated by the Staudinger Reaction. Bioconjug. Chem., 2008, 19, 714-718.

3. Doura, T.; Takahashi, K.; Ogra, Y.; Suzuki, N., Combretastatin A4- $\beta$-Galactosyl Conjugates for Ovarian Cancer Prodrug Monotherapy. ACS Med. Chem. Lett., 2017, 8, 211-214.

4. Dafik, L.; Khosla, C., Dihydroisoxazole Analogs for Labeling and Visualization of Catalytically Active Transglutaminase 2. Chem. Bio., 2011, 18, 58-66.

5. Chen, J.; Wang, J.; Li, K.; Wang, Y.; Gruebele, M.; Ferguson, A. L.; Zimmerman, S. C., Polymeric "Clickase" Accelerates the Copper Click Reaction of Small Molecules, Proteins, and Cells. J. Am. Chem. Soc., 2019, 141, 9693-9700. 